\title{
ASAS NON DISKRIMINASI DALAM CONTEMPT OF COURT
}

\author{
Nur Kholis \\ Program Doktor Ilmu Hukum Universitas Airlangga \\ Kampus B Unair, Jl. Dharmawangsa Dalam Selatan, Surabaya \\ E-mail : n.kholis@gmail.com
}

\begin{abstract}
This research raises the title of non discrimination principle in contempt of Court with legal issue (1). Non-discrimination Principles as the basis for the application of Contempt of Court criminal acts and (2). Formulation of sanction of Contempt of Court crime by using method (1). Normative research type, (2). Approach problems that include (a). Conceptual approach, (b). Legal Approach, (c). Case approach and $(d)$. Comparative approach. The result of this dissertation research in the form of Contempt of court is an insulting behavior, disobedient to the order of the court institution (harassment) which has been included in the criminal law realm. Contempt of court derived from common law system, not derived from countries that the legal system embraces Civil law system including the State of Indonesia. While in Indonesia first knew Contempt of Court on the enactment of Law No. 14 of 1985 on the Supreme Court of the Republic of Indonesia. The Criminal Code (KUHP) does not regulate the crime of Contempt of court, but only acts or criminal acts in the Criminal Code are categorized into the realm of criminal acts Contempt of court, so that the Judge (court) is only a legal object of action criminal Contempt of court. The Non-Discrimination Principle can be applied to the crime of Contempt of Court because all legal subjects must be equal before the law, so that the application of the principle of Non-Discrimination judges will be the subject of law, so there is a shift in the concept of being a legal subject because it is based on the principle of Non Discrimination. The norm as a Contempt of court arrangement is stated as "everyone ...".
\end{abstract}

Keywords : Non Discrimination, Contempt of Court, Equality Before The Law

\begin{abstract}
Abstrak
Penelitian disertasi ini mengangkat judul prinsip non-diskriminasi dalam menghina Pengadilan dengan masalah hukum (1). Prinsip-prinsip Non-diskriminasi sebagai dasar untuk penerapan tindak pidana Contempt of Court dan (2). Perumusan sanksi penghinaan terhadap kejahatan Pengadilan dengan menggunakan metode (1). Jenis penelitian normatif, (2). Pendekatan masalah yang meliputi (a). Pendekatan konseptual, (b). Pendekatan Hukum, (c). Pendekatan kasus dan (d). Pendekatan komparatif. Hasil dari penelitian disertasi ini dalam bentuk Contempt of court adalah perilaku yang menghina, tidak mematuhi perintah institusi pengadilan (pelecehan) yang telah dimasukkan dalam ranah hukum pidana. Penghinaan pengadilan berasal dari sistem common law, bukan berasal dari negara yang sistem hukumnya menganut sistem hukum sipil termasuk Negara Indonesia. Sementara di Indonesia pertama kali tahu Penghinaan Pengadilan tentang diberlakukannya Undang-Undang Nomor 14 Tahun
\end{abstract}


1985 tentang Mahkamah Agung Republik Indonesia. KUHP tidak mengatur kejahatan Penghinaan pengadilan, tetapi hanya tindakan atau tindakan pidana dalam KUHP yang dikategorikan ke dalam ranah tindak pidana Penghinaan pengadilan, sehingga Hakim (pengadilan) hanya menjadi objek hukum tindakan kriminal Penghinaan terhadap pengadilan. Prinsip Non-Diskriminasi dapat diterapkan pada kejahatan Contempt of Court karena semua subjek hukum harus sama di depan hukum, sehingga penerapan prinsip hakim NonDiskriminasi akan menjadi subjek hukum, sehingga terjadi pergeseran dalam konsep menjadi subjek hukum karena didasarkan pada prinsip Non Diskriminasi. Norma sebagai penghinaan terhadap pengaturan pengadilan dinyatakan sebagai "semua orang ...".

\section{Kata Kunci: Non Diskriminasi, Penghinaan Pengadilan, Kesetaraan Dimata Hukum}

\section{A. PENDAHULUAN}

Undang-Undang Dasar Negara Republik Indonesia Tahun 1945 mengamanatkan dengan jelas dan tegas bahwa kekuasaan kehakiman adalah kekuasaan yang merdeka yang artinya terbebas mutlak dari segala bentuk pengaruh dan intervensi dari luar baik dari kekuasaan eksekutif, legeslatif, masyarakat dan pers maupun dari dalam Pengadilan itu sendiri terhadap penyelenggaraan peradilan. Hal ini termaktub didalam Undang-Undang Dasar tahun 1945 bab IX tentang Kekuasaan Kehakiman pasal 24 ayat (1) yang berbunyi "Kekuasaan Kehakiman merupakan kekuasaan yang merdeka untuk menyelenggarakan hukum dan keadilan dan ayat (2) berbunyi "Kekuasaan Kehakiman dilakukan oleh sebuah Mahkamah Agung dan badan peradilan yang berada dibawahnya dalam lingkungan Peradilan Umum, lingkungan Peradilan Agama, lingkungan Peradilan Militer, lingkungan Peradilan Tata Usaha Negara dan sebuah Mahkamah konstitusi”.

Kebebasan hakim atau kemandirian peradilan tidak dapat diartikan sedemikian jauh sehingga membolehkan hakim membuat aturan-aturan sendiri untuk menyelesaikan sengketa yang dihadapkan kepadanya atau memperkenankan untuk membuat putusan secara semenamena, namun hakim berkewajiban untuk menafsirkan suatu aturan. ${ }^{1}$

Suatu Pengadilan yang bebas yang dapat memberikan Pengadilan tanpa dipengaruhi oleh pihak manapun dan dalam bentuk apapun merupakan syarat mutlak bagi suatu Negara hukum. Dalam hal ini Asikin Kusumaatmadja, menyatakan menegakkan Kekuasaan Kehakiman yang bebas, Majalah LPHN, Jilid III Hal ini seperti dinyatakan dalam simposium "Indonesia Negera Hukum" oleh Universitas Indonesia ${ }^{2}$, dengan memberikan kesimpulan sebagai berikut:

1. Pengakuan dan perlindungan hak-hak asasi manusia, yang mengandung persamaan dalam bidang politik, hukum, sosial,ekonomi,cultural dan pendidikan.

\footnotetext{
${ }^{1}$ Sunarto, Peran Aktif Hakim dalam Perkara Perdata, Kencana, Jakarta: 2014, hlm.62

2 Nanda Agung Dewantara, Masalah kebebasan Hakim dalam menangani suatu perkara pidana, Aksara Persada, Jakarta: 2014. hlm.26
} 
2. Pengadilan yang bebas dan tidak memihak, tidak dipengaruhi oleh suatu kekuasaan/kekuatan lain apapaun.

3. Legalitas dalam arti hukum dalam segalanya.

Pengadilan mempunyai pengertian yang menurut van Apeldoorn ialah pemutusan perselisihan oleh suatu instansi yang tidak mempunyai kepentingan dalam perkara maupun bagian pihak yang berselisih, tetapi berdiri diatas merupakan subsumpite Appreaat dan tugasnya ialah menerapkan suatu soal yang jadi pokok peradilan dibawah suatu peraturan umum. $^{3}$

Problematik dalam Indepedensi sebagai harkat dan martabat hakim ini ditandai dengan adanya pengaruh dan intervensi dari luar terhadap penyelenggaraan peradilan, tentu akan menyebabkan lembaga peradilan menjadi tidak merdeka, tidak bebas, tidak independen dan cenderung akan memihak pada salah satu Subjek hukum tertentu (imparsial).

Banyak sekali halnya bentuk dan corak dari pengaruh dan beraneka ragam cara intervensi itu dilakukan. Tindakan berupa suap menyuap dan pemberian gratifikasi secara formal dan non formal sudah jama' dan sudah tidak dapat dibendung lagi gerakannya beserta dengan segala modus operandinya. Secara substantif, terjadinya kasus suap menyuap di Pengadilan yang melibatkan hakim telah menggerogoti dan memporakporandakan bangunan utama profesionalisme para hakim yaitu kemerdekaan atau indepedensi dan ketidakberpihakan atau imparsialitas hakim. Dengan kata lain, kemerdekaan seorang hakim pasti mengalami degradasi moral tatkala menerima suap.

Sementara itu menurut Peter Mahmud Marzuki yang mengutip pendapat dari Lawrence Friedman, profesional paling tidak memerlukan tiga hal, yaitu pengetahuan (knowledge), keterampilan (skill), dan etika (ethics). ${ }^{4}$ Kemerdekaan hakim yang memudar pasti juga menjauhkan keadilan dari mereka yang harus mendapatkan. Alpanya keadilan menandakan keruntuhan hukum. $^{5}$

Pencegahan dan penindakannya (punishment) kepada para hakim beserta jajarannya di semua sektor pengadilan sudah dibuat normatifnya dengan berlakunya Undang-Undang Tindak Pidana Korupsi berserta dengan Undang-Undang tindak pidana pencucian uang. Paling banyak ditemui intervensi yang mengganggu stabilitas kemerdekaan itu bisa berupa pengancaman dan penghinaan yang biasanya berbentuk fisik atau tekanan psikis dan pencemaran nama Hakim beserta Instutusinya (Pengadilan) yang bermuara kepada penghinaan dan pelecehan terhadap marwah, harkat, martabat dan wibawa Hakim dan Pengadilan, keberadaanya sangat urgen akan regulasi atau pengaturan yang dapat dikenakan tindakan pidana terhadap orang dan korporasi sebagai subjek hukum yang menghina dan melecehkan martabat Hakim dan Pengadilan masih belum ada secara konkret sebagai

\footnotetext{
${ }^{3}$ Abdul Mukhtie Fadjar, Sejarah, Elemen dan Tipe Negara Hukum, Setara Press, Malang: 2016, hlm. 54

${ }^{4}$ Peter Mahmud Marzuki, Penelitian Hukum, Prenadamedia, Jakarta: 2012, hlm.14

${ }^{5}$ Antonius Maria Laot Kian, Akuntabilitas Mahkamah Agung, APPTHI, RajaGrafindo Persada, Jakarta: 2016, hlm.207
} 
pelindung dan perisai untuk menjalankan regulasi tugas, tanggungjawab dan fungsi kekuasaan yudisialnya (kehakimannya).

Pada zaman reformasi ini sering tampak secara kasat mata ataupun melalui media massa (televisi), internet maupun koran , situasi didalam ruang persidangan tampak seperti sebuah arena pertandingan tinju yang tidak memakai aturan permainan sama sekali dan sampai boleh dibilang tidak bermoral lagi. Para hadirin sebagai pengunjung sidang didalam persidangan yang berlangsung, tercover dengan jelas sekali berteriak-teriak, mengobrol, bertepuk tangan, memakai pakaian yang tidak sopan, bahkan sampai tangannya menuding-nuding majelis hakim, sebagai contoh pada persidangan Jessica Kumala Wonso yang menghadirkan saksi mantan Menteri Pemuda dan Olah Raga Republik Indonesia Roy Suryo dipersidangan yang sampai Penasihat Hukum dari terdakwa Jessica Kumala Wongso mengatakan dalam peridangan "saudara Roy Suryo kenapa tunjuk-tunjuk Hakim". 6

Seringkali terlihat pula suatu pemandangan "perselisihan" seorang penasihat hukum dengan majelis hakim yang berujung dengan pengusiran penasihat hukum tersebut dari ruang persidangan. Di lain waktu di Pengadilan di Banda Aceh, dalam sidang lanjutan kasus Ketua Sentra Informasi Referendum Aceh (SIRA), Muhammad Nazar, terjadi perang mulut yang mengarah kepada pelecehan-pelecehan atau penghinaan-penghinaan pribadi antara jaksa dan penasihat hukum terdakwa. Hakim yang saat itu bertindak sebagai ketua persidangan tak mampu berbuat banyak. ${ }^{7}$

Selain itu, pada tahun 1986 Advokat Senior Adnan Buyung Nasution juga pernah terjerat tuduhan pelecehan atau penghinaan terhadap lembaga peradilan. Pada perkara Dharsono dikarenakan komentar-komentarnya di majalah Tempo yang dinilai telah menggiring opini massa pada pengadilan yang berpihak.

Kasus Adnan Buyung Nasution ini yang paling populer dikarenakan Adnan Buyung Nasution adalah seorang advocad dan public figure sehingga kasus itu sudah masuk dalam ranah Contempt of Court di dunia peradilan Indonesia. Untuk lebih jelas dan detail kasus tersebut sebagai berikut.

Kasus yang menjerat advocad senior Adnan Buyung Nasution ini, buntut dari perisidangan kasus Tanjung Priok dan Bom BCA Pecenongan dengan terdakwa mantan Pangdam Siliwangi H.R. Dharsono. Dalam suatu sidang, Luhut MP. Pangaribuan dan Buyung meminta kepada Ketua Majelis Hakim Sudiyono menghadirkan saksi a de charge Syarifin Maloko, Kapolres Jakarta Utara Letkol (Pol). Ismet dan kasi intel Kodim Jakarta Utara, akan tetapi permintaan itu dikabulkan. Anggota Tim Pembela H.R. Dharsono, lainnya termasuk Harjono Tjotrosubono, Soekardo Adidjojo, Todung Mulya Lubis dan Amartiwi Saleh.

\footnotetext{
${ }^{6}$ www.detik.com, Tunjuk-tunjuk hakim di sidang Jessica wongso, Roy Suryo buat heboh, 15 September 2016, dikunjungi 10 Mei 2017.

${ }^{7}$ www.hukumonline.com, Menangkal pelecehan di meja hijau, 07 Juni 2003, dikunjungi 16 April 2016
} 
Saat itu, suasana rangkaian sidang-sidang H.R. Dharsono memang panas. Sering terjadi perdebatan antara Luhut MP. Pangaribuan, penasihat Hukum dengan Hakim, atau Penasihat Hukum dengan jaksa Penuntut Umum. Perdebatan hal yang biasa karena di pengadilan adalah kontestasi, tempat adu argumentasi.Belum lagi, sejak mula Luhut MP. Pangaribuan merasakan hakim terlalu berat sebelah dan cenderung berpihak kepada Jaksa.

Ketika membacakan putusan vonis pada tanggal 8 Januari 1986, ada kalimat dari hakim yang berbunyi “...Adalah suatu tindakan yang tidak berdasar dan tidak patut diucapkan di forum ini...Ini suatu pendapat yang terlalu naïf...Ini merupakan suatu tuduhan yang tidak pantas dan tidak etis...".

"Adnan Buyung Nasution protes atas kata-kata Majelis Hakim tersebut, siapa yang tidak etis!" kata Buyung yang berbicara dicorong microphone, "Kami kan sudah meminta saksi dihadirkan...!" tegasnya. Sikap tegas Buyung itu didukung pengunjung sidang yang spontan memberikan tepuk tangan sehingga menjadikan suasana sidang riuh rendah.

Mendengar ribut-ribut antara pembela dan Majelis Hakim, seorang polisi yang tadinya berjaga diluar mendadak langsung masuk ruang sidang dan serta merta memerintahkan pengunjung sidang untuk tetap tenang dan tertib.

Melihat kehadiran polisi yang sekoyong-koyong masuk dan berbicara tanpa izin, namun didiamkan oleh Majelis hakim, Buyung tidak terima.Ia menghardik petugas polisi itu. "Ini ruangan wewenang Hakim, bukan polisi. Polisi keluar!” kata Buyung tegas.

Ribut dan ramai suasana ketika itu. Setelah interupsi, suasana sidang terhenti sekitar satu sampai tiga menit. Majelis Hakim meredakan Susana, menenangkan semua yang hadir. Seingat saya, tidak ada kalimat dari Majelis Hakim yang menghardik Buyung dengan sikapnya tegas itu. Pembacaan putusan kemudian dilanjutkan.

Peristiwa Buyung menginterupsi pembacaan Majelis Hakim itu, besoknya dimuat dihalaman depan Koran-koran Jakarta. Menteri Kehakiman Ismail Saleh menuduh para pembela dari YLBHI telah melecehkan Pengadilan dan wibawa Hakim, atau dengan kata lain telah terjadi Contempt of Court.

Campur tangan Ismail Saleh dalam proses pengadilan itu, sebenarnya aneh juga. Bagaimana ia bisa menyimpulkan telah terjadi Contempt of Court?. Salinan berita persidangan yang ditandatangani Panitera Pengganti Y.Mohammad Sidik dan Hakim ketua Majelis Sudiyono, 8 Januari 1986, yang tidak mencatat kejadian itu dapat disimpulkan Hakim Sudiyono yang memimpin sidang itu, tidak pernah merasa insiden interupsi itu sebagai sesuatu yang penting.

Pemerintah memang seperti kebakaran jenggot dengan interupsi itu, dan insiden itu berbuntut panjang. Ketua PN Jakarta Pusat sebulan kemudian mengeluarkan SK berupa sanksi administrative kepada Buyung dengan mengusulkan kepada Menteri Kehakiman untuk 
mencabut izin prakteknya. Sanksi itu dijatuhkan tanpa pemeriksaan dan kesaksian dari pelaku-pelaku yang ada di lokasi. ${ }^{8}$

Adnan Buyung Nasution dinyatakan melakukan tindak pidana penghinaan terhadap pengadilan (Contempt of Court) karena menginterupsi hakim saat pembacaan vonis putusan terdakwa HR.Dharsono di Pengadilan Negeri Jakarta Pusat pada tanggal 8 Januari 1986. Karena itu, Menteri Kehakiman pada 11 Mei 1987 menskors Buyung 1 tahun tak boleh praktek pengacara, tapi anehnya Buyung tak diseret ke Pengadilan dengan pasal 207 KUHP. Kemudian pada tahun 1987 Mimi Lidyawati dijerat pula dengan tindak pidana Contempt of Court setelah melemparkan sepatunya kearah hakim. ${ }^{9}$ Demikian pula pernah terjadi terhadap advokat Yap Thiam Hiem dalam perkara yang menjadi sorotan publik, saat membacakan pembelaan kliennya yang dianggap merendahkan martabat pengadilan.

Banyak kasus penghinaan martabat pengadilan yang terjadinya sikap para peserta sidang yang tidak puas terhadap putusan hakim, pengacara yang masih memperlihatkan emosi yang berlebihan terhadap seorang saksi yang memberatkan kliennya merupakan hal yang banyak terjadi di pengadilan di Indonesia ${ }^{10}$. Selain itu aksi Contempt of Court yang terjadi adalah perusakan gedung Pengadilan NegeriTemanggung, Jawa Tengah, pada 8 Februari 2011.

Sekarang pada kasus penghinaan terhadap pengadilan atau Contempt of Court bukan lagi terjadi di luar ruang sidang, tetapi penghinaan dan kekerasan justru makin banyak terjadi di ruang-ruang sidang pengadilan. Sederet dari rangkaian kasus-kasus Contempt of Court itu dimulai dari kasus terbunuhnya M. Taufiq, hakim Pengadilan Agama Sidoarjo. Taufiq tewas setelah ditikam Kolonel (AL) M. Irfan saat sang hakim mengadili perkara rebutan harta gono gini antara Irfan dengan mantan isterinya. Pada 29 Oktober 2010 lalu, Selanjutnya kasus PN Temanggung, pada Januari lalu massa mengejar jaksa dan saksi di PN Cibinong. Terakhir sampai ada putusan dari PN Purwakarta Nomor 241/Pid.B/2006/PN.PWK atas nama terdakwa UK yang dalam pertimbangan hukumnya Majelis Hakim telah memberikan reasoning (pertimbangan hukum) yang pada pokoknya dengan memasukkan pertimbangan Contempt of Court.

Meskipun Contempt of Court belum ada pasal yang mengatur dalam ranah hukum pidana Indonesia, perbuatan terdakwa yang dengan Jaksa Penuntut Umum telah didakwa dengan kesatu melanggar pasal 335 ayat 1 ke-1 Kitab Undang Hukum Pidana atau kedua melanggar pasal 310 ayat 1 Jo.pasal 316 KUHP telah dirumuskan oleh Majelis Hakim Pengadilan Negeri Purwakarta telah masuk dalam katagori Contempt of Court meskipun yang terbukti dalam kasus .terdakwa UK tersebut adalah pasal yang telah didakwakan dalam surat dakwaan Jaksa Penuntut Umum.Atas putusan Pengadilan Negeri Purwakarta tersebut,

\footnotetext{
${ }^{8}$ Luhut MP.Pangaribuan, Pengadilan, Hakim, Dan Advocad, Pustaka kemang, Jakarta, 2016 ,. hal.216

${ }^{9}$ www.miftakhulhuda.wordpress.com, Vonis imunitas soemarmo mengutip TEMPO, 6 Mei 1989, dikunjungi 14 April 2017

${ }^{10}$ Lihat koran harian Kompas pada tanggal 02 Maret 2011
} 
sebagai bentuk upaya hukum atas ketidakpuasan putusan Pengadilan Negeri sebagai Pengadilan tingkat pertama itu, pihak Terdakwa UK dan Jaksa Penuntut Umum sama-sama tidak puas sehingga Terdakwa dan Jaksa Penuntut Umum mengajukan upaya hukum Banding ke Pengadilan Tinggi Bandung. Setelah diperiksa oleh Pengadilan Tinggi Bandung dan selanjutnya memberikan putusan, perkara dari Pengadilan Purwakarta dengan Nomor 241/Pid.B/2006/PN.PWK dalam pertimbangannya dikuatkan oleh Majelis Hakim Pengadilan Tinggi Bandung.

Merasa tidak puas lagi akan Putusan Pengadilan Tinggi Bandung, Terdakwa UK mengajukan upaya hukum biasa yang terakhir yaitu kasasi ke Mahkamah Agung Republik Indonesia. Setelah diperiksa dan diadili oleh Majelis Hakim kasasi pada Mahkamah Agung Republik Indonesia, ternyata Majelis Hakim kasasi Mahkamah Agung dengan putusannya menolak kasasi yang diajukan oleh terdakwa.

Dari putusan kasasi yang dilakukan dan diambil oleh Majelis Hakim Mahkamah Agung dapat dibaca dan dipahami secara hukum bahwa putusan perkara Pengadilan Negeri Purwakarta yang memasukkan dalam reasoningnya (pertimbangan hukum) perbuatan terdakwa UK masuk katagori dalam Contempt of Court telah diakomodir putusan Pengadilan Negeri, Pengadilan Tinggi dan dibenarkan serta diamini oleh Mahkamah Agung Republik Indonesia sebagai Pengadilan tingkat terakhir dalam upaya hukum biasa, sehingga pertimbangan (reasoning) itu dapat dijadikan acuan, patokan dan pijakan dalam mengadili perkara yang sama yaitu Contempt of Court, bahkan tidak mustahil putusan itu akan menjadi jurisprudensi tetap dalam ranah hukum pidana.

Sementara itu Suparman Marzuki salah satu mantan komisioner Komisi yudisial Republik Indonesia mengatakan bahwa penghinaan terhadap Pengadilan tidak dapat dibenarkan dan harus dicegah. Apalagi kalau sudah berbentuk kekerasan. Kekerasan diruang sidang Pengadilan adalah masalah serius. ${ }^{11}$

Hal tersebut menunjukkan semakin meningkatnya tindak pidana Contempt of Court yang terjadi akhir-akhir ini dan sekaligus menunjukkan serta mengambarkan bahwa perbuatan dan tindakan yang berujung kepada penghinaan dan pelecehan terhadap lembaga pengadilan tidak terbatas pada kasuskasus tertentu yang menarik perhatian publik (masyarakat yang luas) atau mengundang massa yang banyak, tetapi juga terjadi pula pada saat persidangan tindak pidana biasa maupun dalam ranah perkara-perkara hukum perdata (privat).

Berbagai keadaan situasi dan kondisi yang diskripsikan (digambarkan) di atas kerapkali dan sering kali terjadi dalam perjalanan proses persidangan di pengadilan Indonesia. Pengulangan demi pengulangan kejadian-kejadian tersebut yang seolah tidak ada lagi suatu harapan wadah regulasi norma perlindungan hukum bagi Pengadilan beserta aparaturnya termasuk juga para Hakim. Tindakan-tindakan penghinaan dan pelecehan terhadap peradilan ini sebenarnya bukanlah sesuatu hal yang baru, namun berbagai perbuatan anarkis sebagai tindakan konkret menghina dan pelecehan tersebut semakin sering terjadi semenjak dimulai

\footnotetext{
${ }^{11}$ www.m.hukum online.com, Penghinaan terhadap Pengadilan sudah mengkhawatirkan, 23 Pebruari 2011, dikunjungi 7 Mei 2016
} 
dari tercetusnya era reformasi yang terlalu bebas (menyampaikan pendapat dimuka umum) ataupun sudah amat sangat keblabasan.

Era reformsi yang kebablasan inipun ditunjang dan didukung oleh peran Media masa (Pers) yang sejatinya mempunyai peran saling melengkapi karena bila terjadi hubungan yang baik antara Pengadilan dan Media menimbulkan manfaat yang melampaui bidang hukum penghinaan ${ }^{12}$. Tidak pada saat sekarang ini media (pers) sebelum perkara yang masuk dan sudah masuk dalam persidangan telah dibahas oleh para Nara sumber baik yang berkopenten maupun tidak mempunyai latar belakang ilmu hukum. Sebagai contoh tayangan Televisi Nasional TV one pada acara Indonesia Lawyer Club dengan judul Jessica ${ }^{13}$.

Banyaknya kasus penghinaan dan pelecehan martabat pengadilan yang telah terjadi, namun sangat jarang ditemukan pelakunya sebagai subjek hukum yang dijatuhi hukuman. Hal ini dapat disebabkan oleh karena tidak adanya sumber regulasi norma hukum tertulis (hukum positif) atau perUndang-Undangan yang mengaturnya secara tersendiri dan mandiri, karena selama ini pelaku hanya dapat dijerat dengan beberapa ketentuan yang termaktub didalam Kitab Undang-Undang Hukum Pidana yang hanya mengatur sebagian kecil dari berbagai aksi penghinaan dan pelecehan sebagai perbuatan kejahatan dana pelanggaran dalam ranah Contempt of Court. Untuk mencegah terjadinya penghinaan atau untuk menekan berulangnya penghinaan terhadap peradilan, maka dibutuhkan ketentuan perUndang-Undangan yang khusus mengaturnya. ${ }^{14}$ Menurut teori Utilitarian terdapat 5 (lima) faktor yang mempengaruhi tujuan pencegahan ini yaitu;

1. Tujuan pidana adalah pencegahan (prevention);

2. Pencegahan bukan tujuan akhir tetapi hanya sebagai sarana untuk mencapai tujuan yang lebih tinggi yaitu kesejahteraan masyarakat;

3. Hanya pelanggaran-pelanggaran hukum yang dapat dipersalahkan kepada si pelaku saja (misal karena sengaja atau culpa) yang memenuhi syarat untuk adanya pidana;

4. Pidana harus ditetapkan berdasar tujuannya sebagai alat untuk mencegahan kejahatan;

5. Pidana melihat ke muka (bersifat prospektif); pidana dapat mengandung unsure pencelaan, tetapi baik unsure pencelaan maupun unsure pembalasan tidak dapat diterima apabila tidak membantu pencegahan kejahatan untuk kepentingan kesejahteraan masyarakat.

Jadi, pencegahan kejahatan itu ingin dicapai oleh pidana dengan mempengaruhi tingkah laku si terpidana untuk tidak melakukan tindak pidana lagi. ${ }^{15}$

Ketika tindak pidana Contempt of court banyak dibicarakan oleh kalangan, mereka ada yang setuju untuk dibuatkan regulasi norma dalam bentuk PerUndang-Undangan dan juga ada yang tidak setuju dengan memakai alasan sudah ada tindak pidana Contempt of court

\footnotetext{
${ }^{12}$ World II, New South Law Reform Commision-Discusion Paper, Part One: Liability for sub judice contempt, 1 July 2000.

${ }^{13}$ Youtube, ILC Indonesia Lawyer Club, Jessica.

${ }^{14}$ Ibid

${ }^{15}$ Muladi dan Barda Nawawi Arief, Teori-teori dan Kebijakan Pidana, Alumni, Bandung, 2010, hal.17-18
} 
yang lebih dulu mengatur didalam hukum positif Indonesia yaitu KUHP serta sudah cukup dengan Undang-Undang Pokok Kekuasaan Kehakiman saja karena didalam Undang-undang tersebut sudah begitu luas kekuasaannya hakim dalam menjalankan tugas dan kewajibannya.

Silang pendapat yang terjadi ini dapat diselesaikan dengan kajian hukum dalam prinsip atau asas non diskrimansi yang mempunyai fungsi untuk menelaah secara filosofi dan hukum bahwa tidak pada tempatkanya kalau subjek hukum yang melakukan tindak pidana Contempt of court hanya person-person dari Polisi, Jaksa, Advocad, Masyarakat, akan tetapi berdasarkan asas Non diskriminasi ini, hakim juga termasuk dalam ranah subjek hukum dari pada tindak pidana Contempt of court .

\section{B. PEMBAHASAN}

\section{Asas Non Diskriminasi}

Pada Asas Non Diskriminasi ini yang perlu di berikan penjelasan terlebih dahulu yaitu asas, menurut Black's law dictionary asas adalah; Principle, a basic rule, law, or doctrin. Terjemahan bebasnya adalah Prinsip adalah aturan dasar, hokum, atau doktrin. ${ }^{16}$ Sementara itu menurut para sarjana pengertian azas itu antara lain dari, Luhut MP.Pangaribuan azas adalah fundamental truth or doctrine. ${ }^{17}$ Masih dalam buku tersebut Luhut MP.Pangaribuan mengambil pengertian azas yaitu dari JJ.H.Bruggink, bahwa azas hukum berfungsi baik di dalam maupun dibelakang suatu sistem hukum positip. Sementara Paul Scholten mengatakan bahwa azas hukum adalah pikiran dasar yang terdapat di dalam dan di belakang system hukum masing-masing dirumuskan aturanaturan PerUndang-Undangan dan putusan-putusan Pengadilan yang merupakan penjabarannya. DHM. Meuwissen, menggolongkan azas-azas hukum ke dalam klasifikasi sebagai berikut: Pertama : Azas-azas hukum materiil yang terdiri dari (a) Respek terhadap kepribadian manusia (b) Respek terhadap aspek-aspek kejasmanian dan keberadaan manusia sebagai pribadi (c) Azas kepercayaan yang menuntut sikap timbal balik (d) Azas pertanggungjawaban (e) Azas keadilan : Kemudian yang kedua azas-azas hukum formal yang terdiri dari (a) Azas konsistensi (b) Azas kepastian (c) Azas persamaan. $^{18}$

Sedangkan menurut Mohammad Daud Ali, Azas mempunyai beberapa pengertian salah satu diantaranya adalah kebenaran yang menjadi tumpuhan berfikir atau berpendapat. Selain itu juga berarti alas atau landasan, alas berarti bukti untuk menguatkan suatu keterangan. ${ }^{19}$ Azas hukum pada faktanya sangat penting untuk kebutuhan akan alas pembetukan peraturan PerUndang-Undangan baik dibelakang maupun didalam system hukum positip yang akan dibuat dan diberlakukannya.

\footnotetext{
${ }^{16}$ Black's law dictioniry. Op.cit,. hal.1313

${ }^{17}$ Luhut MP.Pangaribuan, Hukum pidana khusus, Pustaka kemang, Depok: 2016,. hlm.2

${ }^{18}$ Luhut MP.Pangaribuan, Op.Cit,. hlm.2-3

${ }^{19}$ Mohammad Daud Ali, Pengantar hukum dan tata hukum islam di Indonesia, Raja Grafindo Persada, Jakarta: 1991,hlm.114.
} 
Sejalan dengan hal tersebut Peter Mahmud Marzuki menyatakan Azas-azas hukum mempunyai arti penting bagi pembentukan hukum, penerapan hukum dan pengembangan ilmu hukum, Bagi pembentukan hukum, azas-azas hukum memberikan landasan secara garis besar mengenai ketentuan-ketentuan yang perlu dituangkan didalam aturan hukum. Dalam penerapannya hukum sangat membantu bagi digunakannya penafsiran dan penemuan hukum maupun analogi. Adapun bagi pengembangan ilmu hukum azas hukum mempunyai kegunaan, karena didalam azas-azas hukum dapat ditunjukkan berbagai aturan hukum yang pada tingkat yang lebih tinggi sebenarnya merupakan suatu kesatuan. Oleh karena itu penelitian terhadap azas-azas hukum mempunyai mempunyai nilai yang sangat penting baik bagi dunia akademis, pembuatan Undang-Undang maupun praktek Peradilan. $^{20}$

Pengertian dari pada Non Discrimination dapat diambil dari pada Undang-Undang yang menyangkut dengan diskriminasi dan dari kamus hukum. Sementara pada kamus hukum asas non diskriminasi (Non Discrimination) yaitu untuk menghargai persamaan derajat tidak membeda-bedakan, baik para pihak, atas dasar agama, ras, etnis, suku bangsa, warna kulit, status social, afiliasi atau ideology dan sebagainya. Sementara dalam kamus Internasional pengertian non diskriminasi adalah non diskriminasi sebuah tindakan atas kebijakan untuk tidak terlibat dalam diskriminasi. ${ }^{21}$

Selanjutnya dalam Undang-Undang Nomor 39 tahun 1999 Tentang Hak Azazi Manusia (Lembaran Negara nomor 165, Tambahan Lembaran Negara 3886) Pasal 1 ayat 3 berbunyi "Diskriminasi adalah setiap pembatasan, pelecehan atau pengucilan yang lansung ataupun tidak langsung didasarkan pada pembedaan manusia atas dasar agama, suku, ras, etnik, kelompok, golongan, status social, status ekonomi, jenis kelamin, bahasa, keyakinan politik yang berakibat pengurangan, penyimpangan atau penghapusan pengakuan, pelaksanaan atau penggunaan hak azazi manusia dan kebebasan dasar dalam kehidupan baik individual maupun kolektif dalam bidang politik, ekonomi, hukum, sosial, budaya dan aspek kehidupan lainnya".

Undang-Undang nomor 40 tahun 2008 Tentang Penghapusan Diskriminasi Ras dan Etnis (Lembaran Negera nomor 170 Tambahan Lembaran Negera 4919) Pasal 1 ayat 1 berbunyi "Diskriminasi ras dan etnis adalah segala bentuk pembedaan, pengecualian, pembatasan atau pemikiran berdasarkan pada ras dan etnis, yang mengakibatkan pencabutan atau pengurangan pengakuan, perolehan, atau pelaksanaan hak azazi manusia dan kebebasan dasar dalam suatu kesetaraan dibidang sipil, politik, ekonomi, dan budaya”. Asas non diskriminasi adalah asas yang diguna Asas ini adalah asas yang pada dasarnya diterapkan untuk Contempt of Court harus terlebih dahulu dikaji tentang asasasas lain yang menyertai dan berhubungan dengan hak dan kewajiban manusia untuk sama-sama taat pada hukum. Diantaranya asas itu adalah prinsip kesetaraan.

${ }^{20}$ Peter Mahmud Marzuki, ibid,. hlm.119

${ }^{21}$ Kamus - international.com/detination/?indonesia_word=non discrimination . 
Puluhan tahun lamanya semua filsuf terkemuka dunia mengakui bahwa manusia harus mempunyai hak di dunia ini, bahkan manusia itu masih ada dalam kandungan sudah mempunyai hak asasi yaitu hak untuk hidup dimuka bumi. Kelahiran manusia dimuka bumi merupakan suatu momentum tercetusnya akan hak-hak yang melekat pada dirinya yaitu hak asasi manusia pada dasarnya juga manusia disamping mempunyai hak asasi juga mempunyai sesuatu keseimbangan dalam pemenuhan hak-hak asasi itu yaitu berupa kewajiban yang asasi dalam hidupnya. Apabila manusia sudah ada pemenuhan hak asasi dan kewajiban asasi, maka manusia itu akan mempunyai martabat, sebab martabat inilah yang akan dicari manusia sebagai ciptaan tuhan yang paling sempurna dimuka bumi.

Hak asasi manusia juga sering disebut hak kodrat, hak dasar manusia, hak mutlak atau dalam bahasa Inggris disebut Natural Rights, Human Rights, dan Fundamental Rights. Dalam bahasa belanda dikenal Grond rechten, Mensen Regchten dan Rechten Van Mens. Istilah-istilah tersebut menunjukan bahwa titik beratnya iyalah pengakuan adanya hak asasi manusia sendiri. Kongkritnya dalam tataran praktis, hak asasi manusia bergantung tangan dan tidak dapat lepas dari kewajiban asasi dan tanggungjawab. ${ }^{22}$

Khant dalam buku lectures on ethic (1779) menyatakan bahwa nilai manusia mengatasi segala harga, ia tidak memaksudkannya sebagai retorika, melainkan sebagai kesimpulan objektif mengenai tempat manusia. Ada dia fakta penting menyangkut orang-orang yang dalam pandanganya mendukung kesimpulan ini.

Pertama karena orang mempunyai keinginan dan tujuan, hal-hal lain mempunyai nilai bagi mereka dalam hubunganya dengan rencan-rencana mereka. Kedua lebih penting dari itu manusia mempunyai nilai "intrinsik" yakni martabat, karena mereka adalah para pelaku rasional yakni, pelaku bebas yang mampu mengambil keputusan untuk mereka sendiri, menempatkan tujuan-tujuan mereka sendiri dan menentukan perilaku mereka dengan akal budi. ${ }^{23}$

Adanya martabat ini, akan mengejar dan menuntut hak kesederajatan dan kesetaraan dalam kehidupan dengan manusia-manusia lainya. Prinsip kesetaraan dalam hak asasi manusia berpendirian bahwa pada dasarnya menusia itu berkedudukan yang sama atau setara dan sejajar antara satu dan yang lainya mengenai harkat dan martabatnya. Prinsip kesetaraan ini terdapat dalam "Deklarasi Universal Hak Asasi Manusia” yang ditetapkan oleh Majelis Umum dalam resolusi 217A (III) tanggal 10-101998 Pasal 1 yang dinyatakan "Sekali orang dilahirkan merdeka dan mempunyai martabat dan hak-hak yang sama mereka dikaruniai akal budi dan hendaknya bergaul satu sama lainya dalam persaudaraan".

\footnotetext{
${ }^{22}$ A. Masyhur Effendi dan Taufani S. Evandri, Ham dalam Dinamika-Dimensi Hukum Politik, Ekonomi, dan Sosial, Ghalia Indonesia, Bogor 2014, Hal.9

${ }^{23}$ James Rachels, Filsafat Moral, Kanisius, Yogyakarta: 2004, hlm.236-237
} 
Osgar S.Matompo, et.al, mengambil pendapat Rhona K.M. Smits, et.all menyatakan prinsip kesetaraan merupakan prinsip yang mendasar-fundamental dari hak asasi manusia. Prinsip kesetaraan mesyaratkan adanya perlakuan yang setara, yang pada situasi sama harus diperlakukan sama dan dengan perdebatan, pada situasi tertentu (yang berbeda) diperlakukan dengan berbeda pula. ${ }^{24}$ Ketika kesetaraan tidak dapat diraih oleh manusia dalam komunitas kehidupan, maka akan berakibat pada timbulnya perlakuan diskriminasi kepada manusia lainya atau kelompok manusia yang lainya. Timbulnya diskriminasi itu menyebabkan suatu kelompok manusia menguasai mayoritas kemenangan-kemenangan diatas penderitaan manusia lainya. Menurut A. Mahsyur Effendi dan Tauvani S.Evandri mengatakan karena dalam diri hak mengandung makna wewenang/ rights/ tuntutan (Claim). Wewenang atau tuntutan merupakan bagian integral dari hak itu sendiri artinya, ketika hak-hak kemanusiaan diinjak-injak dikesampingkan, disepelekan, dilecehkan dan dilanggar sampai dihapus atau dibuang, secara otomatis akan timbul tuntutan hak untuk pemulihanya. ${ }^{25}$

Pengertian Diskriminasi menurut Black's Law Dictionary

a. The effect of a law or established practice that confers privileges on a certain classor that denies privileges to a certain class because of race, age, sex, nationality, religion, or disability. $\bullet$ Federal law, including Title VII ofthe Civil Rights Act, prohibits employment discrimination based on anyoneofthose characteristics. Other federal statutes, supplemented by court decisions, prohibit discrimination invoting rights, housing, credit extension, public education, and access to public facilities. State laws provide further protections against discrimination. [Cases:Civil Rights 1001-1263.]

b. Differential treatment;esp., a failure to treat all persons equally when no reasonable distinction can be found between those favored and those not favored, ${ }^{26}$ yang dalam terjemahan bebasnya :

a. Pengaruh hukum atau praktik yang tidak dapat dipungkiri berupa penganugerahan hak-hak istimewa pada suatu golongan tertentu atau penolakan hak-hak istimewa kepada suatu golongan tertentu dikarenakan ras, usia, kelamin, kebangsaan, agama, dan kelemahan.

b. Perlakuan berbeda kegagalan dalam memperlakukan semua orang secara setara dengan alasan berbeda yang tidak masuk akal yang di temukan diantara hal yang mereka senangi dan hal yang mereka tidak senangi non diskriminasi.

Perlakuan perbuatan diskriminasi adalah perbuatan melanggar hak asasi manusia dan melanggar hukum, karena perbuatan diskriminasi tersebut dapat merugikan hak asasi orang lain, agar tidak melanggar hak asasi dan melanggar hukum, maka manusia itu seharusnya berepedoman kepada prinsip non diskriminasi.

Non Diskriminasi terdiri dari kata Non dalam bahasa Ingrisnya tidak atau tampa, sementara diskriminasi terjemahanya sudah tertera dalam Blakc's Law Dictionary diatas.

\footnotetext{
${ }^{24}$ Osgar S.Matompo, et.al, Hukum dan Hak Asasi Manusia, Intrans Publishing, Malang: 2018, hlm.14

${ }^{25}$ Mahsyur Efendi dan Tauvani S.Evandri, Op.cit, hlm.9

${ }^{26}$ Black's Law Dictioniry Ibid, Hal.534
} 
Kesimpulanya bahwa asas ini tidak membedakan hak asasi manusia berdasarkan ras, agama, warna kulit, jenis kelamin, politik, dan lain-lainya.

Menurut Osgar S.Matompo et.al mengatakan prinsip non diskriminasi adalah suatu konsep sentral dalam kaedah Hak Asasi Manusia. Prinsip tersebut dapat ditemukan dalam instrument umum Hak Asasi Manusia. Penegasan akan prinsip non diskriminasi ini tercantum dengan jelas beberapa instrumen hak asasi manusia, diantaranya pada Pasal 2 Deklarasi Universal Hak Asasi Manusia yang menyatakan bahwa setiap orang berhak atas semua hak dan kebebasan-kebebasan yang tercantum dalam deklarasi ini dengan tidak ada pengecualian apapun, seperti pembedaan ras, warna kulit, jenis kelamin, bahasa, agama, politik atau pandangan lain, asal usul kebangsaan atau kemasyarakatan, hak milik, kelahiran atau kedudukan lain. ${ }^{27}$

Pada prinsip atau asas Non Diskriminasi nantinya orang atau manusia akan disetarakan untuk mendapatkan hak-hak dipersamakan dimuka hukum atau lebih dikenal dengan asas atau prinsip Equality Before The Law.

Asas equality before the law ini adalah prinsip yang berlaku universal didalam Negara hukum, karena dalam prinsip ini mengandung kesetaraan harkat dan martabat manusia di depan hukum. Prinsip ini juga tercantum dalam Universal Declaration of Human Rights 1948 Pasal 6 yang terjemahanya "Setiap orang berhak atas pengakuan sebagai manusia pribadi terhadap Undang-Undang dimana saja ia berada".

Mengutip dari Jimlly Asshiddiqie dalam bukunya Konstitusi dan Kontitusionalisme Indonesia Hal.151 Negara hukum adalah Negara yang berdaulat yang berdasarkan hukum. Istilah Negara hukum berkaitan dengan paham Rechtsstaat dan The rule of law, juga berkaitan dengan paham nomocraciy yang berasal dari perkataan nomos dan kratos; nomos berarti norma atau kedaulatan hukum. Jadi dalam kaitan dengan kekuasaan tertinggi dalam suatu Negara, menurut paham nomokrasi, kekuasaan tertinggi ada pada norma atau yang berdaulat adalah norma atau hukum (dalam hal ini kedaulatan hukum). Selanjutnya dalam Negara hukum rechtsstaat terdapat cirri-ciri atau unsur-unsur, menurut Friedrich Julius Staal dari kalangan ahli hukum Eropa Barat continental sebagai berikut :

a. Mengayomi dan melindungi hak-hak asasi manusia.

b. Untuk melindungi hak asasi manusia tersebut, maka penyelenggaraan Negara harus berdasarkan pada teori Trias Politica.

c. Dalam menjalankan tugasnya, pemerintah berdasarkan Undang-Undang.

d. Apabila menjalankan tugasnya berdasarkan Undang-Undang pemerintah masih melanggar hak asasi (campur tangan pemerintah dalam kehidupan pribadi seorang) maka ada pengadilan adiministrasi yang akan menyelesaikan. ${ }^{28}$

\footnotetext{
${ }^{27}$ Osgar S.Matompo, et.al Op. cit, Hal.16

${ }^{28}$ Anwar.C, Teori dan Hukum Konstitusi, Setara Perss, Malang: 2015, hlm. 46
} 
Tujuan dari prinsip Equality Before The Law adalah keadilan pada setiap manusia didepan hukum. Hukum itu terilhami karena dalam rangka mencari keadilan sejati. Keadilan merupakan titik pangkal dibentuknya peraturan hukum yang memuat hak dan kewajiban. $^{29}$

Menurut Muhammad Syukri Albani Nasution, et.al tujuan hukum tertinggi adalah keadilan. Adil artinya melakukan segala sesuatu sesuai dengan porsinya. Dengan meletakkan sesuatu secara proposional berarti keadilan adalah ketertiban dan kedisiplinan. Kesesatan merupakan tindakan yang melanggar prinsip proposional, ketertiban dan kedisiplinan. ${ }^{30}$

Asas atau prinsip Proporsional menurut kamus hukum adalah suatu asas yang meletakkan segala kegiatan sesuai dengan konteks atau tujuanya tersebut, baik yang dilakukan oleh warga Negara, Institusi maupun aparatur pemerintah yang dilandasi oleh etik individual, etik social, dan etik institusional. ${ }^{31}$

Menurut Agus Yudha Hernoko, Prinsip atau asas proporsional tidak dilihat dari konteks keseimbangan-matematis (Equilibrum), tetapi pada proses dan mekanisme hak dan kewajiban secara fair. Selanjutnya untuk mencari makna visiologi keadilan, Agus Yudha Hernoko mengambil filsuf besar seperti Aristoteles, menyatakan bahwa "Justice Consists in treating equals equally and uneqoalss unequally, in propotion to dare ine qually" (prinsip bahwa yang sama diperlakukan secara sama dan yang tidak sama juga diperlakukan tidak sama secara proporsional). Ulpianus menggambarkan keadilan adalah kehendak yang terus menerus dan dapat memberikan kepada masing-masing apa yang menjadi haknya (to give everybody is own) demikian pula pandangan dari Paul Tillich, L.J.van, J.van Can dan J.H. Beekhuis, yang menyatakan bahwa keadilan itu memperlakukan sama terhadap hal yang sama dan memperlakukan yang tidak sama sebanding dengan ketidaksamaanya. ${ }^{32}$

Makna dari asas atau prinsip hukum kesetaraan, non diskriminasi, Equaliti Before The Law, dan prinsip Proporsional terhadap tindak pidana Contempt of Court adalah hukum seharusnya memandang manusia sebagai Subjek hukum yang mempunyai kualitas kesetaraan dalam hak dan kewajibanya, oleh karena itu, maka manusia sebagai Subjek hukum dilarang untuk memperlakukan manusia lainya secara diskriminatif terhadap hak dan kewajibanya dalam hukum, dengan tidak melakukan manusia lainya secara diskriminasi, maka manusia yang mempunyai harkat dan martabat di muka hukum harus pula diperlakukan secara sama di didepan hukum dengan memperhatikan proporsional dalam memandang hukum sebagai norma. Memperhatikan asas itu semua yang saling berhubungan satu dengan yang lainya, maka asas non diskriminasi dapat diterapkan

\footnotetext{
${ }^{29}$ A.M.Agus Santoso, Hukum, Moral dan Keadilan, Kencana, Jakarta: 2014, hlm.129

${ }^{30}$ Muhhamad Syukri Albani Nasution, et.al, Op. Cit, hlm. 208

${ }^{31}$ Charllie Rudiat, Op.Cit, hlml.70

${ }^{32}$ Agus Yudha Hernoko, Hukum Perjanjian Asas Proporsionalitas Dalam Kontrak Komersial, Kencana, Jakarta: 2013, hlm.84-85
} 
kepada Subjek hukum. Apabila Subjek hukum yaitu masyarakat, Jaksa, Polisi, Advokad, bahkan Hakim harus mempunyai kedudukan yang sama didepan hukum, sehingga hakim tidak ada perbedaan perlakuan terhadap tindak pidana Contempt of Court, karena dapat diterapkanya ke-4 (empat) asas tersebut kepada hakim.

Fungsi dari prinsip kesetaraan, nondiskriminasi, Equality Before The Law, dan proporsional adalah untuk mencapai keadilan didepan hukum. Pada dasarnya pengetahuan tentang tindak pidana Contempt of Court adalah tindak pidana yang ditunjukan kepada Subjek hukum dan korporasi yang menghina pengadilan dan marwah, martabat hakim baik yang dilakukan tindak pidana itu diluar persidangan maupun di dalam persidangan yang sedang berlangsung (due process law).

Berdasarkan fundamental dari ke-4 (empat) asas yang telah di kemukakan, makna dan fungsi Contempt of Court dapat diperluas untuk mencapai keadilan bersama didepan hukum. Para hakim yang semula dalam tataran konsep Contempt of Court bukan termasuk kedalam katagori atau ranah Contempt of Court, sekarang sudah berubah paradigma dengan beralasan kepada ke-4 (empat) asas-asas hukum tersebut, maka hakim juga dapat dikenakan atau diberlakukan tindak pidana Contempt of Court, dengan demikian asas Non-Diskriminasi dapat diterapkan karena adanya asas Equality Before The Law.

Secara filosofi asas Non Diskrimanasi hanya mempunyai tujuan yaitu terciptanya hokum dan keadilan di segala bidang, karena hokum dan keadilan adalah sangat dibutuhkan dalam peradaban pergaulan umat manusia yang majemuk dimuka bumi ini sebagai mahluk zoon politicon. Hukum dan keadilan tidak boleh dipisah-pisahkan oleh karena keduanya ibarat uang yang bermata dua yang selalu menjadi satu kesatuan yang utuh.

Otje Salman mengambil filsuf hukum terkemuka Gustav Radbruch menjelaskan bahwa "Hukum itu adalah hasrat kehendak untuk/demi mengabdi keadilan ...Apabila hukum/Undang-Undang secara sadar/sengaja mengingkari keadilan, misalnya secara seenaknya dan tidak menentu kepada manusia memberikan tetapi sekaligus juga menolak hak-hak asasinya, maka Undang-undang yang demikian itu kehilangan kekuatan berlaku mengikatnya, karena itu pula rakyat tidak wajib mentaatinya. ${ }^{33}$

Asas Non Diskriminasi senantiasa memberikan salah satu solusi atau jalan keluar bagi persoalan-persoalan tindak pidana Contempt of court di Indonesia, karena sampai saat ini hanya ada pada tataran pengertian secara harfiah saja, tetapi pada tataran norma hokum belum ada regulasi dalam hokum positif, sehingga berakibat tindak pidana Contempt of court tidak dapat dikenakan kepada subjek hukum yang benar-benar menghina pengadilan dan hakim sebagai wakil tuhan.

\footnotetext{
${ }^{33}$ Otje Salman, Filsafat Hukum, Refika Aditama, Bandung: 2009, hlm.58.
} 
Pengadilan dan hakim sebagai wakil tuhan adalah jabatan yang diberi kekuasaan yang merdeka oleh karena hakim yang hanya mempunyai tugas kepanjangan tangan dari tuhan kerena hanya hakim yang diperbolehkan oleh Undang-undang untuk mencabut nyawa manusia, sehingga tugas hakim hanya dalam ranah menegakkan hukum dan keadilan. Dalam menegakkan hukum dan keadilan tersebut, hakim wajib memperlakukan setiap subjek hukum atau manusia harus sama didepan hukum karena setiap subjek hukum mempunyai kesetaraan didepan hokum. Ketika subjek hokum itu sudah ada kesetaraan didepan hokum, maka secara proporsional, hakim juga wajib dianggap subjek hukum yang juga apabila melakukan kesalahan dalam tindak pidana, maka hakim tersebut tidak lagi menyandang wakil tuhan, akan tetapi sudah masuk sebagai subjek hukum biasa yang tidak kebal terhadap hukum.

Perilaku hakim yang menyimpang tidak boleh diskriminasi terhadap penegakan hukum dan keadilan karena nanti akan berkibat kepada pelemahan terhadap hukum dan keadilan, maka dalam mencapai suatu penegakan hukum dan keadilan dapat diberlakukan asas Non Diskriminasi dan inilah hubungan antara asas Non Diskriminasi dengan prinsip kesetaraan, prinsip equlity before the law dan pinsip proporsional.

Contempt of court yang pada tataran konsepnya adalah perbuatan yang menghina pengadilan dan hakim baik dilakukan didalam persidangan maupun diluar persidangan, bagi siapa saja yang menghina pengadilan dan hakim, maka dengan adanya asasnya Non Diskriminasi telah bergeser pada tataran konsepnya yaitu hakim dapat menjadi dan pelaku bagian dari tindak pidana Contempt of court, sehingga nantinya hakim juga menjadi subjek hukum dari pada Contempt of court dan ini juga merupakan fungsi dari asas Non Diskriminasi pada tindak pidana Contempt of court.

\section{Sejarah Contempt Of Court di Inggris}

Keberadaan Contempt of Court pertama kali muncul di negara-negara yang menganut system hukum common law. Menurut Luhut M.P. Pangaribuan Contempt of Court apabila dilihat dari system hukumnya berasal dari system keluarga hukum common law atau keluarga hukum Anglo-Saxon. ${ }^{34}$ Dalam system common law (Hukum Inggris), setiap orang yang melakukan pelanggaran terhadap Undang-Undang pidana harus memenuhi unsur-unsur sebagai berikut:

a. Tertuduh telah melakukan perbuatan yang dituduhkan atau dikenal dengan dengan istilah Actus-reus dan;

b. Tertuduh melakukan pelanggaran terhadap Undang-Undang dengan disertai niat jahat atau dikenal dengan istilah Mens-rea ${ }^{35}$

${ }^{34}$ Luhut M.P. Pangaribuan, Op.Cit, hlm.17

${ }^{35}$ Romli Atmasasmita, Perbandingan Hukum Pidana, Mandar Maju, Bandung: 1996, hlm. 56 
Oleh karena itu Contempt of Court sejatinya tidak dikenal didalam keluarga hukum civil law system yang menurut hukum pidana Belanda, didalam setiap tindak pidana pada prinsipnya harus memuat unsure-unsur : a) conduct atau tindakan, dan b) keadaankeadaan yang relevan yang menyertai atau "relevance circumstances", ${ }^{36}$ termasuk Negara Republik Indonesia, akan tetapi perilaku dari Contempt of Court yang telah diatur di keluarga hukum common law system sudah sering kali terjadi dan terus berulang-ulang sehingga perilaku yang sering melanggar Contempt of Court ini hanya menjadi tontonan belaka yang tanpa adanya aksiologisnya.

Di Negara-negara yang sistem hukumnya menganut common law pasti mempunyai tiga karateristik yaitu Yurisprudensi dipandang sebagai sumber hukum yang terutama karena merupakan suatu produk dari perkembangan yang wajar hukum Inggris yang tidak dipengaruhi oleh hukum Romawi, dianutnya doktrin stare dicisis atau yang dikenal di Indonesia dengan dokrin "preseden", yaitu hakim terikat untuk menerapkan putusan pengadilan terdahulu baik yang ia buaat sendiri atau oleh pendahulunya untuk kasus serupa dan adanya adversary system dalam proses peradilan. Dalam system ini, kedua belah pihak yang bersengketa yang masing-masing menggunakan lawyer-nya berhadapan didepan seorang hakim. Ketiga hal itu merupakan pembeda fundamental antara sistem common law dari sistem civil law. ${ }^{37}$

Sementara menurut Romli Atmasasmita karakteristik dari common law system adalah sebagai berikut:

a. Custum yang merupakan sunber hukum yang tertua di Inggris. Oleh karena itu ia lahir dan berasal dari sebagian hukum romawi.

b. Legeslation berarti Undang-Undang yang dibentuk melalui parlemen.

c. Case law sebagai salah satu sumber hukum Inggris merupakan ciri karekteristik yang utama. Seluruh hukum kebiasaan yang berkembang didalam masyarakat tidak melalui parlemen, akan tetapi dilakukan oleh para hakim, sehingga dikenal dengan istilah "judge made law"38

Sementara menurut Peter de Cruz, Negara-negara Common Law secara umum adalah Negara-negara yang gaya yuristiknya didasarkan pada model common law Inggris, yang terutama didirikan berdasarkan pada system kasus atau preseden yudisial, dan dimana legeslasi secara tradisional tidak dianggap sebagai sumber hukum utama, tetapi biasanya dianggap sebagai hanya sekedar sarana konsolidasi atau klarifikasi dari peraturan prinsip hukum yang secara esensial diturunkan dari hukum kasus dan hukum yang dibuat oleh hakim. ${ }^{39}$

\footnotetext{
${ }^{36}$ Romli Atmasasmita, Ibid, hlm.59.

${ }^{37}$ Peter Mahmud Marzuki, Op. Cit, h. 250-251

${ }^{38}$ Romli Atmasasmita, Op.Cit, hlm. 35-36

${ }^{39}$ Peter de Cruz, ibid, hlm. 62
} 
Negara Inggris yang menganut system strict liability yang sering diartikan secara singkat liability without fault (pertanggungjawaban tanpa kesalahan). Menurut common law, strict liability berlaku terhadap 3 macam delik;

a. Public nuisance (gangguan terhadap ketertiban umum, menghalangi jalan raya, mengeluarkan bau yang tidak enak yang mengganggu lingkungan);

b. Crimnal libel (fitnah, pencemaran nama);

c. Contempt of Court (pelanggaran tata tertib pengadilan) ${ }^{40}$

Dilihat dari sejarahnya Contempt of Court dahulu kala sebuah pengadilan yang keberadaannya adalah untuk mewakili raja inggris sebagai jelmaan wakil tuhan di dunia, memberi hukuman kepada siapa saja tanpa pandang bulu yang teraang-terangan melawan titah perintah atau larangan yang dikeluarkan oleh rajanya. Hukuman dan sanksi itu dijatuhkan oleh raja sebagai penguasa tunggal, karena ia adalah sebagai raja atau raja sebagai pribadi bukan sebagai lembaga kerajaan dan raja bertanggung jawab pada Tuhan. Raja mempunyai kekuasaan paling tinggi dan raja merupakan sumber keadilan, sumber hukum dan kemudian mendelegasikan kekuasaannya pada aparatnya dalam hal ini lembaga peradilan. Jadi seseorang yang melakukan Contempt of Court sama identik dengan "contempt of the king", sehingga pidana yang dijatuhkan sangat berat. ${ }^{41}$

Sejak tahun 1742, Negara Inggris telah memberlakukan dan menerapkan Contempt of Court dengan berdasarkan pada doktrin Pure streams of justice yang dianggap sebagai dasar untuk memberlakukan Contempt of Court yang kemudian pada tahun 1981 diadakan pembaharuan dengan diterapkannya Contempt of Court Act 1981, sementara Amerika Serikat yang merupakan rumpun dari system hukum commom law juga mengundangkan Contempt of Court pertama kalinya pada 1789.

Pengaturan tentang Contempt of Court dimaksudkan untuk menegakkan dan menjamin proses peradilan berjalan tanpa rongrongan dari berbagai pihak, antara lain pihak yang terlibat dalam proses peradilan, mass media, maupun pejabat pengadilan itu sendiri. Pengaturan Contempt of Court merupakan upaya hukum untuk membela kepentingan umum dan supremasi hukum agar proses peradilan dapat dilaksanakan dengan sewajarnya dan adil, tanpa diganggu, dipengaruhi atau dironggrong oleh pihakpihak lain, baik selama proses peradilan berlangsung di Pengadilan maupun di luar gedung Pengadilan. ${ }^{42}$

Menurut hukum Inggris Contempt of Court diatur pada Contempt of Court act 1981 yang memberikan sanksi kriminal termasuk juga hukuman penjara kepada siapapun pihak

\footnotetext{
${ }^{40}$ Barda Nawawi Arief, Perbandingan hukum pidana, RajaGrafindo Persada, Jakarta: 2013, hlm.39.

${ }^{41}$ Wahyu Wagiman, "Contempt of Court dalam rangcangan KUHP”, elsam, Jurnal Dinamika Hukum, No. 2, Vol. 9, 2009, hlm..5

${ }^{42}$ Andi Sofyan dan Abd.Asis, Hukum Acara pidana, ibid, h.384-385.
} 
yang melakukan perbuatan ikut mencampuri urusan pengadilan pada saat terjadi pemeriksaan perkara di persidangan. ${ }^{43}$

\section{Karakteristik Contempt Of Court}

\section{a. Contempt Of Court dalam Kitab Undang-Undang Hukum Pidana (KUHP)}

Pada dasarnya aturan-aturan yang mengatur tentang jenis-jenis Contempt of Court di Negara Indonesia secara implisit ada dan termaktub didalam Kitab UndangUndang Hukum Pidana (KUHP) dan juga diluar KUHP serta di Kitab UndangUndang Hukum Acara Pidana (KUHAP), diantaranya didalam Kitab UndangUndang Hukum Pidana terdapat karekteristik di dalam Pasal-Pasalnya.

Penjabaran dari karekteristik Pasal-Pasal yang terkait secara langsung dengan Contempt of Court baik yang terkandung didalam Kitab Undang-Undang Hukum Pidana dan di luar Kitab Undang-Undang Hukum Pidana dapat dijelaskan sebagai berikut;

\section{1) Menghina.}

Pada tataran menghina ini adalah suatu kareteristik yang sangat krusial, dikarenakan pada pengertian Contempt of Court dalam Black's law dictinory dengan tegas mengartikan bahwa yang namanya orang yang melakukan perbuatan contempt yaitu ditujukan untuk menghina badan peradilan.

Sedangkan untuk kata menghina itu sendiri dalam hukum pidana dapat dikemukan oleh para pakar hukum pidana lewat doktrin dan jurisprudensinya, diantaranya;

Menurut R. Soesilo yang terdapat dalam pasal 207 KUHP yang termasuk dalam kategori pasal Contempt of Court mempunyai terjemahan;

a) Pasal ini menjamin alat kekuasaan Negara supaya tetap dihormati. Tiap-tiap penghinaan terhadap alat-alat tersebut dihukum menurut pasal ini.

b) Menghina dengan lisan atau tulusan = menyerang nama baik dan kohormatan dengan kata-kata atau tulisan.

c) Supaya penghinaan ini dapat dihukum harus dilakukan dengan sengaja dan dimuka umum, jika dilakukan dengan tulisan, misalnya dengan surat kabar, majalah, panflet dsb. Harus dibaca oleh khalayak ramai.

d) Objek yang dihina itu ialah sesuatu kekuasaan (badan kekuasaan pemerintah) seperti Gubernur, Residen, Polisi, Bupati, Camat dsb, atau suatu majelis umum (parlemen, dewan perwakilan rakyat daerahdsb.). Gubernur, Residen dsb.itu bukan orangnya. Jika yang dihina itu orangnya sebagai pegawai negeri sedang melakukan kewajiban jabatannya yang sah, dikenakan pasal 216.

43 http://www.yuridis.com/upaya-kejaksaan-agung-inggris-terkait-contempt-of-court-akibat-twitter/, dikunjungi pada tanggal 29 November 2018 
Mr. W.F.L. Buschkens mengemukakan bahwa menurut putusan Mahkamah Agung 29 Nopember 1938 maka penghinaan terhadap seorang bupati dalam hal ini harus dipandang sebagai penghinaan terhadap suatu kekuasaan yang telah ditetapkan. $^{44}$

Menurut Adami Chazawi, et.al., bahwa dengan menggunakan kata menghina atau penghinaan yang dalam teks aslinya beledigen bukan minachting, maka penghinaan ringanpun masuk dalam pengertian penghinaan menurut pasal 207 KUHP. ${ }^{45}$ Kata penghinaan juga terdapat pada pasal 208. Apa yang disampaikan oleh Moeljatno memperkuat pendapat bahwa, perkataan penghinaan (belidigen) dalam tindak pidana-tindak pidana khusus (terutama yang terdapat di dalam KUHP), diartikan yang sama dengan bebtuk-bentuk penghinaan umum di dalam Bab XVI Buku II KUHP. ${ }^{46}$

Menurut Soenarto Soerodibroto yang mengutip dari putusan-putusan (jurisprudensi) Mahkamah Agung Republik Indonesia sebagai berikut;

- Penghinaan secara pribadi kepada pegawai negeri waktu sedang menjalankan jabatan dengan sah adalah merupakan penghinaan kepada suatu badan kekuasaan Negara. (MA No.121 K/Kr/1968 tanggal 11 Maret 1970).

- Hakim dan Jaksa termasuk dalam pengertian kekuasaan yang ada dalam Negara Republik Indonesia termasuk dalam pasal 207 KUHP (MA No.10 $\mathrm{K} / \mathrm{Kr} / 1964$ tanggal 1-9-1964). ${ }^{47}$

\section{2) Sengaja}

Karasteristik dalam KUHP yang termasuk dalam Contempt of Court kedua adalah sengaja atau kesengajaan. Perbuatan untuk dapat sampai pada delik pidana Contempt of Court harus dilakukan dengan cara sengaja. Sementara "kesengajaan" dalam teori ilmu hukum yang dikemukan oleh para pakar hukum pidana baik itu dari akedemisi maupun praktisi dalam khazanah ilmu hukum, dapat dijelaskan dibawah ini, karena kesengajaan sebagai element penting dari kejatahan yang dilakukan oleh orang (person), diantara teori kesengajaan tersebut dikemukakan oleh;

Mr. M.H. Tirtaamidjaja ada tiga bentuk sengaja;

a) Sengaja sebagai maksud (oogmerk)

Harus dibedakan dari motif perbuatan itu. Orang yang melakukan perbuatan itu pada perbuatannya telah memaksudkan terjadinya akibat itu.

b) Sengaja (dengan keinsyafan pasti, ..opzet bij zekerheids-bewustzijn")

\footnotetext{
${ }^{44}$ R. Soesilo, Kitab Undang-Undang Hukum Pidana (KUHP) beserta komentar-komentarnya, Politea, Bogor: 1996, hlm.164.

${ }^{45}$ Adami Chazawi, et.al., Tindak Pidana Pres, op cit, hlm.140.

${ }^{46}$ Adami Chazawi, et.al.,ibid, hlm. 140

${ }^{47}$ Soenarto Soerodibroto, KHUP dan KUHAP dilengkapi Yurisprudensi Mahkamah Agung dan Hoge Raad, PT. RajaGrafindo Persada, Jakarta, cetakan kelima, 2000, hlm.120-121.
} 
Dalam hal mana orang yang melakukan perbuatan yang benar tidak memaksudkan terjadinya suatu akibat tertentu (sengaja sebagai maksud) dalam hal mana akan tetapi ia mempunyai kepastian atau yakin bahwa akibat itu akan terjadi.

Pada bentuk ini sengaja itu sebagai maksud orang yang melakukan perbuatan itu ditujukan pada suatu akibat tertentu. Ia pasti tahu atau telah yakin benar, bahwa oleh perbuatannya disamping akibat yang dimaksudnya (sengaja sebagai maksud) akan terjadi akibat lain.

c) Sengaja (dengan keinsyafan akan kemungkinan; voorwaardelijk opzet, dolus eventualis)

Dalam hal mana orang yang melakukan perbuatan tidak memasukkan suatu akibat tertentu ataupun tidak mempunyai kepastian atau tidak berkeyakinan bahwa akibat itu akan terjadi, akan tetapi telah mengira-ngirakan kemungkinan akan terjadinya akibat itu. Namun, walaupun demikian tidak menahan nafsu untuk melakukan perbuatan itu.

Sementara itu menurut Mr. H.A. Zainal Abidin Farid Untuk mengetahui benar atau tidaknya pendapat para sarjana hukum pidana itu, maka perlu dipelajari dua teori,yaitu:

a) Teori kehendak (Wilstheorie)

Teori ini diajarkan oleh von Hippel, guru besar di Gottingen, Jerman, yang berpendapat bahwa Vorsatz (kesengajaan) adalah kehendak untuk melakukan suatu perbuatan dan kehendak untuk menimbulkan akibat karena perbuatannya itu, seperti yang dirumuskan di dalam Undang-Undang pidana. Yang menyetujui teori ini ialah Vos yang berpendapat bahwa M.v.T. menganut teori ini yang menggunakan istilah willens en wetens, yaitu menghendaki dan mengetahui. Jonkers juga menganut teori ini yang menyatakan bahwa kehendaklah yang merupakan hakikat kesengajaan. Untuk perbuatan, yaitu gerakan otot teori kehendak tidak menemukan kesulitan. Diakuinya bahwa untuk akibat dan keadaan yang menyertai perbuatan (begeleidende omstandigheden), misalnya bahwa barang yang diambil harus dengan maksud untuk dimiliki dengan melawan hukum (pasal 362 KUUHP), penentuan adanya kehendak itu agak sukar. Itulah sebabnya sebagian sarjana hukum pidana berpendapat bahwa akibat dan keadaan yang menyertai perbuatan tidak mungkin dikehendaki, tetapi hanya dapat dibayangkan kemungkinan akan terwujudnya, maka kemudian lahirlah teori membayangkan (voorstellingstheorie). Menurut ; Jonkers, bahwa kehendaklah yang mendominir kesengajaan, dan bahwa hal itu berlaku untuk perbuatan (formel opzet = kesengajaan nisbi) disetujui oleh semua sarjana hukum. Menurut Jonkers bahwa hal itu beriaku juga bagi akibat dan keadaan yang menyertai perbuatan (materieel opzet), oleh karena bukanlah bayangan yang menyebabkan orang berbuat, tetapi kehendak (wil). Diakui oleh Jonkers bahwa mungkin saja tembakan tidak 
mengenai sasaran, atau tikaman pisau dapat ditangkis, tetapi tidak berarti bahwa akibat yang tidak terwujud itu tidak dikehendaki. la tetap dikehendaki, dan kalau akibat tidak terwujud, maka pembuat delik masih dapat dipidana melakukan percobaan untuk menghilangkan nyawa orang lain. Akibat yang tidak terwujud itu disebabkan oleh keadaan di luar kehendak penembak atau penikam.

b) Teori membayangkan (voorstellingstheorie)

Kalau teori kehendak diajarkan oleh von Hippel pada tahun 1903 dalam bukunya berjudul "Die Grenze von Vorsatz und Fahrlassigkeit, maka pada tahun 1907, Frank guru besar di Tubingen dalam karangan berjudul Ueber den Aufbau des Schuldbegriffs, dalam Festschrift Giezen, menentang teori von Hippel. Berdasarkan alasan psikologis, tidaklah mungkin suatu akibat dapat dikehendaki. Yang dapat dikehendaki ialah perbuatan sedangkan akibat hanya dapat diingini, diharapkan dan dibayangkan kemungkinan akan terwujudnya; ${ }^{48}$

Seperti halnya para pendapat para sarjana yang dari kalangan civil law system, yang semuanya sepakat bahwa corak dari pada kesengajaan dibagi 3 (tiga) juga. Di Negara-negara yang menganut Eropa Kontinental, para pengarang membedakan tiga corak (gradatie) kesengajaan yaitu;

a) Opzet als oogmerk yaitu sengaja sebagai maksud.

b) Opzet bij noodzakelijkheidsbewustzijn atau bij zeker heidsbewustzijn yaitu sengaja sadar atau insaf akan keharusan atau sadar akan kepastian, yang oleh Utrecht diuraiakan dan diterjemahkan sebagai sengaja dengan insyafan bahwa, agar tujuan dapat tercapai, sebelumnya harus dilakukan suatu perbuatan lain yang berupa pelanggara pula, dan

c) Opzet bij mogelijkheidsbewustzijn, dolus eventualis, eventualiter atau voorwaardelijk opzet (van Hammel), opzet bij waarschijnlijkheidsbewustzijn (D. Hazewinkel-Suringa) atau konsopzet (W. Nieboer) atau sengaja sadar kemungkinan, sengaja bersyarat (van Hamme), sengaja sadar akan kemungkinan besar (Pompe dan hazewinkel-Suringa).

Selanjutnya mengambil definisi dari Vos yang memberikan definisi sengaja sebagai maksud terjadi jikalau pembuat delik menghendaki akibat perbuatannya dengan kata lain, andai kata pembuat sebelumnya sudah mengetahui bahwa akibat perbuatannya tidak terjadi, maka sudah tentu ia tidak pernah melakukan perbuatannya.

\section{b. Bentuk-bentuk Contempt Of Court}

Contempt of Court di masa sekarang, berada pada titik yang sangat absurd dan kurang jelas. Konsep yang menjiwainya sering dikaburkan dan dikonfrontasikan dengan prinsip transparansi, kontrol yudisial maupun kebebasan mengeluarkan

${ }^{48}$ Zainal Abidin Farid, Hukum pidana 1, Sinar grafika, Jakarta, cetakan ketiga: 2010, hlm.282-284. 
pendapat atas nama demokrasi dan reformasi. Regulasi Contempt of Court yang pada mulanya merupakan konsep untuk mencegah dipengaruhi dan diintervensinya peradilan, semakin bergeser dari arah semula melindungi badan peradilan menuju ide kontrol terhadap kekuasaan kehakiman, baik yang terlembagakan secara formal, maupun oleh publik dan masyarakat umum secara langsung.

Jenis Contempt of Court yang kerap terjadi dan dilakukan terhadap Pengadilan di masa sekarang dengan merujuk pada pengkatagorian dari Oemar Seno Adjie tersebut di atas adalah jenis disobeying a court order, the sub judice rule dan scandalizing the court. Hal ini mungkin muncul seiring dengan era kebebasan berkumpul \& berpendapat dari segala lapisan masyarakat, juga sebagai akibat langsung dari masa reformasi yang langsung atau tidak, meniadakan sekat-sekat pembatas opini, kekebasan pers sekaligus ajang unjuk gigi dan kekuatan antar kelompok bahkan antar lembaga Negara.

\section{1) Disobeying a court order}

Pengabaian terhadap panggilan dari pengadilan, kerap dilakukan oleh pihak yang merasa tidak pantas dihadirkan di pengadilan. Dan biasanya ini terkait kedudukan dirinya, entah dalam struktur pemerintahan ataupun strata sosial kemasyarakatan. Padahal telah jelas ketentuan dalam Pasal 27 ayat (1) UndangUndang Dasar 1945, bahwa: "Segala warga Negara bersamaan kedudukannya di dalam hukum dan pemerintahan dan wajib menjunjung hukum dan pemerintahan dan wajib menjujung hukum dan pemerintahan itu dengan tidak ada kecualinya", tidak peduli itu Rakyat atau presiden, tidak peduli itu penjahat atau pejabat. Setiap warga Negara harus menjunjung tinggi hukum, tanpa kecuali. Dan tidak dapat dibantah pula, pengabaian terhadap panggilan dari pengadilan baik itu sebagai saksi yang dimintai keterangannya, maupun sebagai pihak yang bersengketa, merupakan pengabaian terhadap hukum dan pemerintahan, juga secara otomatis merupakan pengingkaran terhadap ketentuan Undang-Undang Dasar 1945.

Sering ditemui dalam praktek bahwa Pejabat Tata Usaha Negara sebagai kapasitasnya pejabat negara yang dipanggil ke persidangan di Pengadilan, mengabaikan panggilan itu dengan alasan "merasa tidak pantas diadili" atau alasanalasan lain yang tidak masuk akal. Hal ini secara praktek dapat di maklumi apabila Pejabat Tata Usaha Negara itu berkedudukan sebagai pihak yang bersengketa, kemudian menguasakan kepada bawahannya atau kuasa hukumnya. Permasalahan muncul ketika Pejabat Tata Usaha Negara itu diminta keterangan dan kesaksiannya dalam persidangan, seringkali tidak muncul dan mengirimkan bawahanya untuk memberikan kesaksian. Padahal seorang saksi dalam hukum wajib dating untuk memberikan keterangan atas hal yang apa yang diketahuinnya, apa yang dilihat dan didengarnya secara langsung.

2) The sub judice rule 
Amerika Serikat mengartikan The sub Judice rule berbanding lurus dengan Contempt of Court sebagai misbehavior in the presence of the court or so near threato as to obstruct the administration. Jika diterjemahkan secara bebas membawa pengertian Tindak tanduk yang tidak wajar di muka pengadilan atau tempat berdekatan dengannya, sehingga dapat merintangi proses peradilan.

Contempt of Court di masa -masa sekarang, berada pada titik yang sangat rendah dan kurang jelas makna dan pengertiannya. Konsep penghinaan yang menjiwainya sering dikaburkan dan dikonfrontasikan dengan prinsip atau asas transparansi, kontrol yudisial maupun kebebasan mengeluarkan pendapat yang diluar batas moral atas yang tidak jarang mengatas namakan demokrasi dan reformasi. Regulasi Contempt of Court yang pada mulanya merupakan konsep untuk mencegah dan tidak menghina lembaga pengadilan, mempengaruhi dan diintervensinya lembaga peradilan, semakin bergeser dan dimarginalkan oleh gagasan kontrol terhadap kekuasaan kehakiman yang menyangkut tekhins judicial, baik yang terlembagakan secara formal, maupun oleh publik dan masyarakat umum secara langsung dengan memberikan pendapat yang seharusnya dan seyogyanya tidak boleh dikomentari karena sudah menyangkut tekhnis persidangan sampai pada tahap akhir yaitu pembacaan vonis atau putusan hakim.

\section{3) The sub judice rule}

Ada pendapat yang menyatakan bahwa selain kekuasaan Eksekutif, Legislatif dan Yudikatif dalam teori Trias Politikanya Montesquei, ada pula kekuatan lain diluar kekuasan, eksekutif, kekuasaan lehestalif dan kekuasaan kehakiman yang menjadi penyeimbang dari seluruh kekuasaan tersebut, yakni pers yang merdeka. Mentransparankan peranan pers setelah sangat terkekang selama masa orde baru, merupakan sinyalemen positif dalam kehidupan berdemokrasi, berbangsa dan berNegara. Akan tetapi ini juga menjadi masalah ketika pers dengan mulai masuk dan menjadi penyeimbang berita yang sangat mempengaruhi proses peradilan.

\section{4) Scandalizing the court}

Hakim adalah manusia biasa yang bisa saja khilaf, yang diembani amanah untuk memeriksa, memutuskan dan menegakkan hukum dan keadilan. Itulah prinsip yang perlu dipahami terlebih dahulu. Sehingga kesalahan dan kekeliruan terhadap putusan sebagai produk yang dihasilkannya, pasti ada seperti yang terjadi pada putusan kasus Sengkon dan Karta. Akan tetapi bukan berarti oleh karena adanya kesalahan dan kekeliruan dari Hakim yang manusia biasa ini, setiap orang berhak melakukan koreksi dan evaluasi tanpa prosedur hukum. Melainkan harus menempuh proses hukum dan aturan yang telah ada atau seperti Undang-Undang mengaturnya dalam mekanisme atas ketidakpuasan terhadap putusan yang telah diambil secara bermusyawarah oleh Majelis Hakim.

\section{Keterkaitan antara Asas Non Diskriminasi dengan Contempt Of Court}


Secara umum hukum dibangun dan diterapkan harus memenuhi 3 (tiga) unsure, dari ke 3 (tiga) unsur ialah;

a. Asas-asas hukum (legal principles)

b. Norma-norma hukum (legal norm) dan

c. Aturan-aturan hukum (legal rules)

Asas-asas hukum melahirkan suatu atau sejumlah norma-norma hokum, dan selanjutnya norma hukum akan melahirkan suatu atau sejumlah aturan-aturan hokum, salah satu contohnya;

a. Asas hukum; asas pengakuan hak milik individu, melahirkan antara lain,

b. Norma hukum; dilarang menggangu hak milik seseorang, kemudian melahirkan,

c. Aturan hukum; antara lain pasal 362 KUHP (setiap orang yang mengambil barang sebagian atau seluruhnya milik orang lain, dengan maksud untuk seolah-olah dimiliki, dengan jalan melawan hukum, dipidana karena pencurian). ${ }^{49}$

KUHP secara khusus tentang delik Contempt of court tidak ada aturannya, akan tetapi perbuatan atau delik yang menyerupai bentuk-bentuk dari tindak pidana Contempt of court terdapat dalam KUHP yaitu dimulai dari Pasal 207, 209, 210. 211, 212, 212, 216, 217, 224, dan 233 KHUP. Pasal-Pasal tersebut yang dikatagorikan masuk ke dalam ranah tindak pidana Contempt of court tidak dapat dikenakan kepada hakim atau hakim tidak dapat menjadi subjek hukum dalam ranah tindak pidana Contempt of court karena pada kerangka konsepnya tindak pidana Contempt of court hanya dapat dikenakan subjek hukum diluar hakim (pengadilan).

Pasal-Pasal yang dinayatakan dalam KHUP sebagai katagori tindak pidana Contempt of court tersebut, kurang dapat mencerminkan rasa keadilan dalam hokum, karena hakim hanya menjadi objek daripada tindak pidana Contempt of court. Sebagai jalan untuk tindak pidana Contempt of court ini dapat diberlakukan pada setiap orang (subjek hokum), maka asas Non Diskriminasi ini dapat diterapkan didalam tindak pidana Contempt of court, dengan alasan bahwa setiap orang sama didepan hokum dan hukum berlaku kepada setiap orang, bukan berlaku tebang pilih.

Asas Non Diskriminasi sudah sebagai aturan pokok yang tidak dapat diuji lagi karena sudah sebagai asas hukum, jadi keadilan dalam penerapan hakim sebagai subjek hokum sudah sangat beralasan secara hokum dan inipun nanti dapat dilahirkan norma "setiap orang".

\section{PENUTUP}

\section{Kesimpulan}

\footnotetext{
${ }^{49}$ Ahmad Ali, ibid, h.176-177
} 
Kitab Undang-Undang Hukum Pidana tidak mengatur tentang tindak pidana Contempt of court, akan tetapi hanya perbuatan atau tindak pidana dalam Kitab UndangUndang Hukum pidana dikatagorikan masuk kedalam ranah tindak pidana Contempt of court, sehingga Hakim (pengadilan) hanya menjadi objek hukum dari tindak pidana Contempt of court. Asas Non Diskriminasi dapat di terapkan terhadap tindak pidana Contempt of Court karena seluruh subjek hukum harus sama didepan hukum, sehingga dalam penerapan asas Non Diskriminasi hakim akan menjadi subjek hukum, jadi ada pergerseran konsep yang dari semula Hakim menjadi objek hukum sekarang juga masuk sebagai subjek hukum karena didasari oleh asas Non Diskriminasi. Norma sebagai pengaturan Contempt of court dinyatakan dengan "setiap orang".

\section{Saran}

Bahwa Hakim juga harus dimasukkan kedalam tindak pidana Contempt of Court sebagai Subjek hukum, karena berdasarkan Asas Non Diskriminasi semua Subjek hukum harus diperlakukan sama didepan hukum, apabila Subjek hukum itu melanggar hukum dalam tindak pidana Contempt of Court.

\section{DAFTAR PUSTAKA}

\section{Buku :}

A. Masyhur Effendi dan Taufani S. Evandri, Ham dalam Dinamika-Dimensi Hukum Politik, Ekonomi, dan Sosial, Ghalia Indonesia, Bogor: 2014.

A.M. Agus Santoso, Hukum, Moral dan Keadilan, Kencana, Jakarta: 2014.

Abdul Mukhtie Fadjar, Sejarah, Elemen dan Tipe Negara Hukum, Setara Press, Malang: 2016.

Agus Yudha Hernoko, Hukum Perjanjian Asas Proporsionalitas Dalam Kontrak Komersial, Kencana, Jakarta: 2013.

Antonius Maria Laot Kian, Akuntabilitas Mahkamah Agung, APPTHI, RajaGrafindo Persada, Jakarta: 2016.

Anwar.C, Teori dan Hukum Konstitusi, Setara Perss, Malang: 2015.

Barda Nawawi Arief, Perbandingan hukum pidana, RajaGrafindo Persada, Jakarta: 2013.

James Rachels, Filsafat Moral, Kanisius, Yogyakarta: 2004.

Luhut MP.Pangaribuan, Hukum pidana khusus, Pustaka kemang, Depok: 2016. , Pengadilan, Hakim, Dan Advocad, Pustaka kemang, Jakarta, 2016

Mohammad Daud Ali, Pengantar hukum dan tata hukum islam di Indonesia, Raja Grafindo Persada, Jakarta: 1991. 
Muladi dan Barda Nawawi Arief, Teori-teori dan Kebijakan Pidana, Alumni, Bandung: 2010. Nanda Agung Dewantara, Masalah kebebasan Hakim dalam menangani suatu perkara pidana, Aksara Persada, Jakarta: 2014.

Osgar S.Matompo, et.al, Hukum dan Hak Asasi Manusia, Intrans Publishing, Malang: 2018.

Otje Salman, Filsafat Hukum, Refika Aditama, Bandung: 2009.

Peter Mahmud Marzuki, Penelitian Hukum, Prenadamedia, Jakarta: 2012.

R. Soesilo, Kitab Undang-Undang Hukum Pidana (KUHP) beserta komentar-komentarnya, Politea, Bogor: 1996.

Romli Atmasasmita, Perbandingan Hukum Pidana, Mandar Maju, Bandung: 1996.

Soenarto Soerodibroto, KHUP dan KUHAP dilengkapi Yurisprudensi Mahkamah Agung dan Hoge Raad, PT. RajaGrafindo Persada, Jakarta, cetakan kelima: 2000.

Sunarto, Peran Aktif Hakim dalam Perkara Perdata, Kencana, Jakarta: 2014.

World II, New South Law Reform Commision-Discusion Paper, Part One: Liability for sub judice contempt, 1 July 2000.

Zainal Abidin Farid, Hukum pidana 1, Sinar grafika, Jakarta, cetakan ketiga: 2010.

\section{Jurnal :}

Wahyu Wagiman, “Contempt of Court dalam rangcangan KUHP”, elsam, Jurnal Dinamika Hukum, No. 2, Vol. 9, 2009.

\section{Sumber Lain :}

Black Law Dictionary

www.detik.com, Tunjuk-tunjuk hakim di sidang Jessica wongso, Roy Suryo buat heboh, 15

September 2016, dikunjungi 10 Mei 2017.

www.hukumonline.com, Menangkal pelecehan di meja hijau, 07 Juni 2003, dikunjungi 16

April 2016

www.miftakhulhuda.wordpress.com, Vonis imunitas soemarmo mengutip TEMPO, $6 \quad$ Mei 1989, dikunjungi 14 April 2017

Lihat koran harian Kompas pada tanggal 02 Maret 2011 www.m.hukum online.com, Penghinaan terhadap Pengadilan sudah mengkhawatirkan, 23

Pebruari 2011, (dikunjungi 7 Mei 2016. 
http://www.yuridis.com/upaya-kejaksaan-agung-inggris-terkait-contempt-of-court-akibattwitter/, dikunjungi pada tanggal 29 November 2018 